\title{
A systematic review of motivation of sport event volunteers
}

\author{
EUNJUNG KIM \\ Department of Tourism, Sport and Hotel Management, Griffith Business School, \\ Griffith University, Gold Coast Campus, Southport, Queensland, Australia
}

\begin{abstract}
The aims of this paper are to summarise the current status of the literature on motivation of sport event volunteers and identify research gaps in order to suggest a research agenda for the future research. It develops a better understanding of approach to sport event volunteers' motivation and how it could be applied to volunteer management in sport events. Through a systematic review method, this study searched and categorised 33 original peer reviewed research papers published in English language academic journals. From the review, this paper updates new database and suggests that a wide range of motivation represented by sport event volunteers may be considered to apply an effective volunteer management for successful sport events.
\end{abstract}

Key words: Sport events, Volunteers, Motivations, Human resource management 


\section{Introduction}

Recruitment of volunteers as an important part of sport event human resource management process is a vital issue to hold a successful sport event (Sharififar, Ganjouie, Tondnevis, \& Zarei, 2011). Volunteers are invaluable human resources at events (Lockstone, Smith, \& Baum, 2010), spending their skills, knowledge, time, and effort. The volunteers particularly in sport events may be perceived as episodic volunteers compared to continuous volunteers who engage in a long-term volunteering. In many ways, episodic volunteering at sport events may be different from other volunteering.

By increasing the significance of sport event volunteering, Farrell, Johnston, and Twynam (1998) suggested that organisers should understand motivation of volunteers for the effective volunteer management in terms of recruitment, retention, and daily operations of sport events. Previous researches on sport event volunteers have advanced the body of knowledge about motivation on sport event volunteerism and further sport event volunteer management in particular by exploring the relation between satisfaction, commitment, and retention. For example, Wicker and Hallmann's (2013) study presented a review of the literature on individual and institutional perspectives to reveal theoretical and methodological shortcomings which their paper attempts to address. A multi-level framework combining both perspectives and multi-level analysis could open new perspectives for research on volunteers in sport to investigate the drivers of the decision to volunteers. Drawing from researches that have examined motivation of sport event volunteers, it is possible to undertake a systematic review in order to identify, describe, and compare the available systematic evidence about motivation for sport event volunteers. While previous researches on motivation of sport event volunteers have contributed to the advancement of theory and practice of volunteer management in sport event context, to the best of my knowledge, no studies have attempted to examine a systematic review about motivation of sport event volunteers with regard to improving ultimately their intention to continue volunteering at sport events. The systematic review may provide a better understanding of approach to sport event volunteers’ motivation, current issues, and research gaps for researchers to help in designing and developing a future research agenda. Identifying the motivation of sport event 
volunteers through a systematic review is likely to enhance a considerable body of literature discussing the motivation for sport event volunteering.

Therefore, the purpose of this review is to examine the nature and extent of peer reviewed research literature on motivation of sport event volunteers through an established systematic review method. A greater understanding of motivation of sport event volunteers may be possible to develop an effective volunteer management for operating a successful sport event.

\section{Sport event volunteering}

The International Labour Organisation (ILO, 2011, p.13) defined volunteering as “unpaid noncompulsory work; that is time individuals give without pay to activities performed either through an organisation or directly for those outside their own household.” According to the Johns Hopkins Centre for Civil Society Studies (2014), approximately 140 million people in the 37 countries studied participate in volunteer work in a typical year, representing $12 \%$ of the total adult population of those countries and $44 \%$ of the non-profit workforce in those countries. If those 140 million volunteers comprised the population of a country, it would be the $8^{\text {th }}$ largest country in the world. Besides, volunteers make US $\$ 400$ billion contribution to the global economy that would be in the $7^{\text {th }}$ largest economy in Europe.

Many sectors of society have derived benefits from the help of volunteers. The sectors of sport and event, especially, have relied heavily on volunteers who constitute a significant human resource to host a successful event. Events are typically dependent on episodic volunteers who get involved in more flexible, short-term, and once-off volunteering (Holmes \& Smith, 2009; Lockstone et al., 2010) and episodic volunteering is likely to become more common in the context of sport events. For example, the 2000 Sydney and 2004 Athens Olympic Games recruited over 40,000 volunteers who contributed approximately 4.5 million hours (Cuskelly, Hoye, \& Auld, 2006). If those volunteers were paid \$10/hour, the cost for volunteer labour would have been \$45 million (Doherty, 2009). The 2008 Beijing Olympic Games utilised 100,000 volunteers for the competition venues, the Olympic villages, and transportation (Yan \& Chen, 2008) and 70,000 volunteers were involved in the 2012 London 
Olympic Games (International Olympic Committee, 2013). The 2016 Rio de Janeiro Olympic Games expect to need the help of 70,000 volunteers (Flueckiger, 2015). Likewise, the 2010 FIFA World Cup South Africa received the help from 15,000 Organising Committee volunteers and 3,000 volunteers for the Host Cities and the Football for Hope tournament (FIFA, 2010). At the 2014 FIFA World Cup Brazil, FIFA and the Local Organising Committee could get the enough support of 15,000 volunteers who played a key role in ensuring the event operations ran smoothly (FIFA, 2014). There will be about 5,500 volunteers involved in the FIFA Confederations Cup 2017 and 15,000 in the 2018 FIFA World Cup Russia (FIFA, 2016).

Given the substantial contribution of volunteers in sport events, it is significant to pay attention to the main factors of sport event volunteering in regard to motivation, satisfaction, commitment, and retention of volunteers. From this point of view, it is required to distinguish among the types of volunteers and the features of events in which they volunteer as volunteers differ in motive, expectation, and level of commitment. It can be applied to meeting the need of episodic volunteers in sport events in this study. Yoshioka, Brown, and Ashcraft (2007) argued that the understanding the motives of different volunteers is necessary for volunteer managers to manage volunteers effectively and design a volunteer program that satisfy the interests of potential volunteers. To attract sport event volunteers, therefore, the event organisers and volunteer coordinators should recognise the motivation of sport event volunteers and the relation to satisfaction, commitment, and retention of those volunteers.

\section{Sport event volunteer motivation}

Attitudes, beliefs, values, and personality are main causes that make individuals disparate and form their motivation when they engage in an activity (Chelladurai, 2006). Motivation is about being inspired to do an activity, and has been adapted in a wide range of contexts including workplaces, learning, events commitment and, as relevant here, volunteer activity. The categorising of reasons for volunteering has varied and been complex, depending on types of events and organisations (Bang \& Ross, 2009). Such diversity is reflected in this research into volunteer motivation, particularly about 
sport event volunteers. It seems that the motivation of sport event volunteers could be different from those of non-sport event volunteers.

With a comprehensive view of volunteer motivation in the area of human services, Clary et al. (1998) used a functional approach to develop volunteer function inventory (VFI) under six broad functions: values, understanding, social, career, protective, and enhancement. Values referred to one’s altruistic and humanitarian concerns for others. Understanding related to exercising one’s skills, abilities, and knowledge as well as opportunities for learning experiences. The social function was about involving social interaction and networking. Career comprised relevant benefits obtained from engaging in a volunteer work. Protective referred to one’s guilt reduction and addressing one’s personal problems. Enhancement related to the ego's growth and personal development. Clary et al. (1998) argued that volunteers with high scores among VFI factors are likely to intend to continue to volunteer. Güntert, Neufeind, and Wehner (2015) used the VFI to state the total match index which explained additional variance (e.g. good citizenship, excitement) in satisfaction and retention of volunteers in the context of sport events. Based on the VFI dimensions, they predicted unique variance and demonstrated the impact of the set of motives measured by the VFI.

Although Clary et al.'s (1998) scale is applicable to all contexts of volunteer motivation, there is most probably a difference in volunteer motivation at sport events. This perspective is supported by several studies (e.g. Bang \& Chelladurai, 2003; Farrell et al., 1998; Giannoulakis, Wang, \& Gray, 2007) on motivation of sport event volunteers.

Farrell et al. (1998) pointed out that "motivation for special event volunteer is different from that for other volunteers” (p. 295). The special event volunteer motivation scale (SEVMS) by Farrell et al. (1998) was developed to focus on particularly sport event volunteers at a woman's curling competition in Canada in 1996. Four categories were grouped: purposive, solidary, external traditions, and commitments. Purposive referred to contribution to event and community. Solidary related to social interaction, group identification, and building networks. External tradition linked to traditions regarding family and external influences. Commitments were about expectation and responsibilities 
from others. The findings demonstrated their suggestion that special event volunteers may experience multiple motivations and volunteer's satisfaction with overall experiences is not only a function of fulfilling their expectations, but also associated to their satisfaction with the facilities and the organisation of the event (Farrell et al., 1998). Further studies on volunteer motivation in sport events (e.g. Dickson, Benson, Blackman, \& Terwiel, 2013; Dickson, Benson, \& Terwiel, 2014; Dickson, Darcy, Edwards, \& Terwiel, 2015, Khoo \& Engelhorn, 2007; Khoo \& Engelhorn, 2011; Twynam, Farrell, \& Johnston, 2002) provided support for the application of the SEVMS in sport event contexts.

Bang and Chelladurai (2003) established the volunteer motivation scale for international sporting events (VMS-ISE) in the sample of the 2002 FIFA World Cup. This six factor scale consisted of an expression of values (related to altruistic values for other people), patriotism (feeling of belonging, pride, community spirit), interpersonal contacts (friendship and social network), career orientation (opportunities for new career and learning career-relevant skills), personal growth (feeling of selfworth and self-esteem), and extrinsic rewards (related to free admission, uniform, and food). It was likely to measure volunteers' motivation in international sporting events with a valid and reliable scale. Bang and Ross (2009) further proposed seven factors with the inclusion of one more factor, named love of sport (loving the sport and liking any event of the sport) and changed a factor name from patriotism to community involvement. They investigated whether volunteers were willing to support the country and the sport event in order to make it a success. In this sense, the VMS-ISE explained the attractiveness of sport as one of volunteer's strong motives. The adaption of VMS-ISE has been found in the several studies in the review (e.g. Bang, Alexandris, \& Ross, 2008; Bang \& Ross, 2009; Bang, Won, \& Kim, 2009; Hallmann \& Harms, 2012; VanSickle, Pierce, \& Diacin, 2015). Findings provided a better understanding of various subgroup differences in volunteer motivation at sport events.

Giannoulakis et al. (2007) examined the Olympic volunteer motivation scale (OVMS) including three categories: Olympic related (a desire of volunteers to be associated with the Olympic movement or meet with Olympic athletes), egoistic (a need for social interaction, and networking), and purposive (a willingness of volunteers to benefit with their actions). Although the OVMS factors consisted of 
fewer items, Olympic-related motivation was found to be a main factor. It could be attributed to the distinct nature of the Olympic Games.

\section{Methods}

A systematic review was carried out using a methodology which has been used in various reviews (Petticrew, 2001). According to Pickering and Byrne (2014), it was currently developed between the more traditional narrative and systematic weighted methods. By using systematic review methods, research papers are searched and categorised in the relevant literature and it provides reproducible and reliable assessments of the current status of a field of research (Roy, Byrne, \& Pickering, 2012). The results of quantitative assessment might be geographical spread of the literature, spread of the literature by year, key concepts and theories used, types of methods used, and sorts of results obtained.

Original peer reviewed research papers published in English language journals on the motivation of sport event volunteers were obtained by searching electronic databases including Google Scholar, ProQuest, Scopus, Science Direct, Sage as well as author’s university library between January and May 2016. Key words used for the searching were 'motivation of sport event volunteer' and a combination of the following terms; 'volunteer management', 'commitment', 'intention to continue', 'retention', ‘participation', ‘volunteering', ‘recruitment', ‘satisfaction', and 'engagement'. However, academic papers related with words such as 'non-profit organisation not in sport events' (e.g. Red Cross, first aid, charity), ‘sports club’ (e.g. rugby club, football club) and ‘non-sport events’ (e.g. cultural events, business events) were excluded. Papers that searched by databases had been peer reviewed and published in English academic journals and reports such as conference proceedings or theses as well as books and book chapters were not included. The reference lists of these articles were also used to find additional academic papers as the first articles appeared in various databases were frequently cited and recently published.

From each academic research paper examining motivation of sport event volunteers, the following information was recorded in a Microsoft Excel database; author, their affiliation, journal name, year of publication, country where research was conducted, methods used in the research (e.g. method for 
collecting data, type of data, scale of sample), key concepts, key measurement model/scale and theories used as well as the overall results.

The methods used for data collection in academic papers were classified in several ways such as survey, interview, focus group, observation, and participant observation. The type of data and scale of sport events were also recorded. The type of data collected was examined as quantitative, qualitative or mixed method. Key measurement model/scale and theories were classified depending on whether they were applied and assessed in their research. Finally, overall results categorised by research questions were presented in order to understand that how motivation was investigated and linked to other concepts with regard to volunteer management.

This study is desire to identify motivation of sport event volunteers in the literature and state research gaps for the future research. This research, therefore, has presented five aspects such as nature of research and author (e.g. study location, year of publication, journal field distribution), methods used, key measurement model/scale, theories related to motivation of sport event volunteers, and overall results categorised by research questions. Finally, the discussion will explain why this review is important for the further research and how motivation research contributes to the possibility that volunteers are more involved in sport event volunteering.

\section{Results}

A total of 33 academic peer reviewed research papers on motivation of sport event volunteers were published from 1995 to 2015 (see Appendix). In the Appendix, this paper identified more specific knowledge of each study to find out which studies mentioned.

\section{Geographic scope}

The research had been done in 11 different countries. Most papers were from the United States (29.4 \%), Canada (17.6 \%), Norway (11.8 \%), and the United Kingdom (11.8 \%) (see Table 1). There were relatively few peer reviewed research papers from Australia (5.9\%), Germany (5.9 \%), Greece (5.9 \%), Iran (2.9\%), Switzerland (2.9\%), Malaysia (2.9\%), and New Zealand (2.9\%). Of $39.8 \%$ 
authors studying motivation of sport event volunteers were affiliated with institutions in the United States at the time of their publication. However, as four authors among them in the United States were active more than one research, altogether, there were different 32 authors. Other authors' affiliations at the time of publication were Canada (15.1\%), Norway (11.8 \%), the United Kingdom (8.6 \%), Australia (7.5\%), and Iran (4.3\%). In the case of Canada, there were different nine authors in affiliation with institutions in Canada because four authors were involved in more than one research. Different seven authors each in Norway and the United Kingdom conducted their studies as two authors in Norway and one author in the United Kingdom got involved in more than one research. As regards Australia, a total of five different authors investigated the relevant research in this field because one author was active in the three research papers. There were three authors with affiliations in Switzerland, two authors each from Germany, Malaysia, and New Zealand, and one each from Greece, Austria, and Taiwan.

Table 1. The number of study location and author (based on author affiliations) examining motivation of sport event volunteers in the peer reviewed research papers by country

\begin{tabular}{lcccc}
\hline \multirow{2}{*}{ Country } & \multicolumn{2}{c}{ Study location } & \multicolumn{2}{c}{ Author } \\
\cline { 2 - 5 } & $\mathrm{N}$ & $\%^{2}$ & $\mathrm{~N}$ & $\%^{2}$ \\
\hline United States & 10 & 29.4 & 37 & 39.8 \\
Canada & 6 & 17.6 & 14 & 15.1 \\
Norway & 4 & 11.8 & 11 & 11.8 \\
United Kingdom & 4 & 11.8 & 8 & 8.6 \\
Australia & 2 & 5.9 & 7 & 7.5 \\
Germany & 2 & 5.9 & 2 & 2.2 \\
Greece & 2 & 5.9 & 1 & 1.1 \\
Iran & 1 & 2.9 & 4 & 4.3 \\
Switzerland & 1 & 2.9 & 3 & 3.2 \\
Malaysia & 1 & 2.9 & 2 & 2.2 \\
New Zealand & 1 & 2.9 & 2 & 2.2 \\
Austria & - & - & 1 & 1.1 \\
Taiwan & - & - & 1 & 1.1 \\
\hline Total & $34^{1}$ & \multicolumn{4}{c}{} \\
\hline
\end{tabular}

${ }^{1}$ Total $>33$. One paper by Dickson et al. (2014) examined motivation of sport event volunteers in two different countries.

${ }^{2}$ Does not add to $100 \%$ due to rounding. 


\section{Scope by year}

The 33 peer reviewed research papers involved in the systematic review are represented in a cumulative frequency distribution chart (see Figure 1). The mean number of papers published annually during the 21 years period of this review is 1.6. To classify trends in the volume of research publications the period covered by this review (1995 to 2015) was divided into two nearly equal time periods (one of 11 years and one of 10 years). From 1995 to 2005, papers were only published as none or one by each year. However, there was a significant increasing in motivation of sport event volunteers research publications from the first period (1995 to 2005) with six publications to the second period (2006 to 2015) with 27 publications. That is more than four times the number of published research papers ten years ago. As a proportion of the total research papers reviewed $18.2 \%$ were published between 1995 and 2005 compared to 81.8 \% published from 2006 to 2015. Over fourfifths of peer reviewed research papers on motivation of sport event volunteers were published from 2006 to 2015.

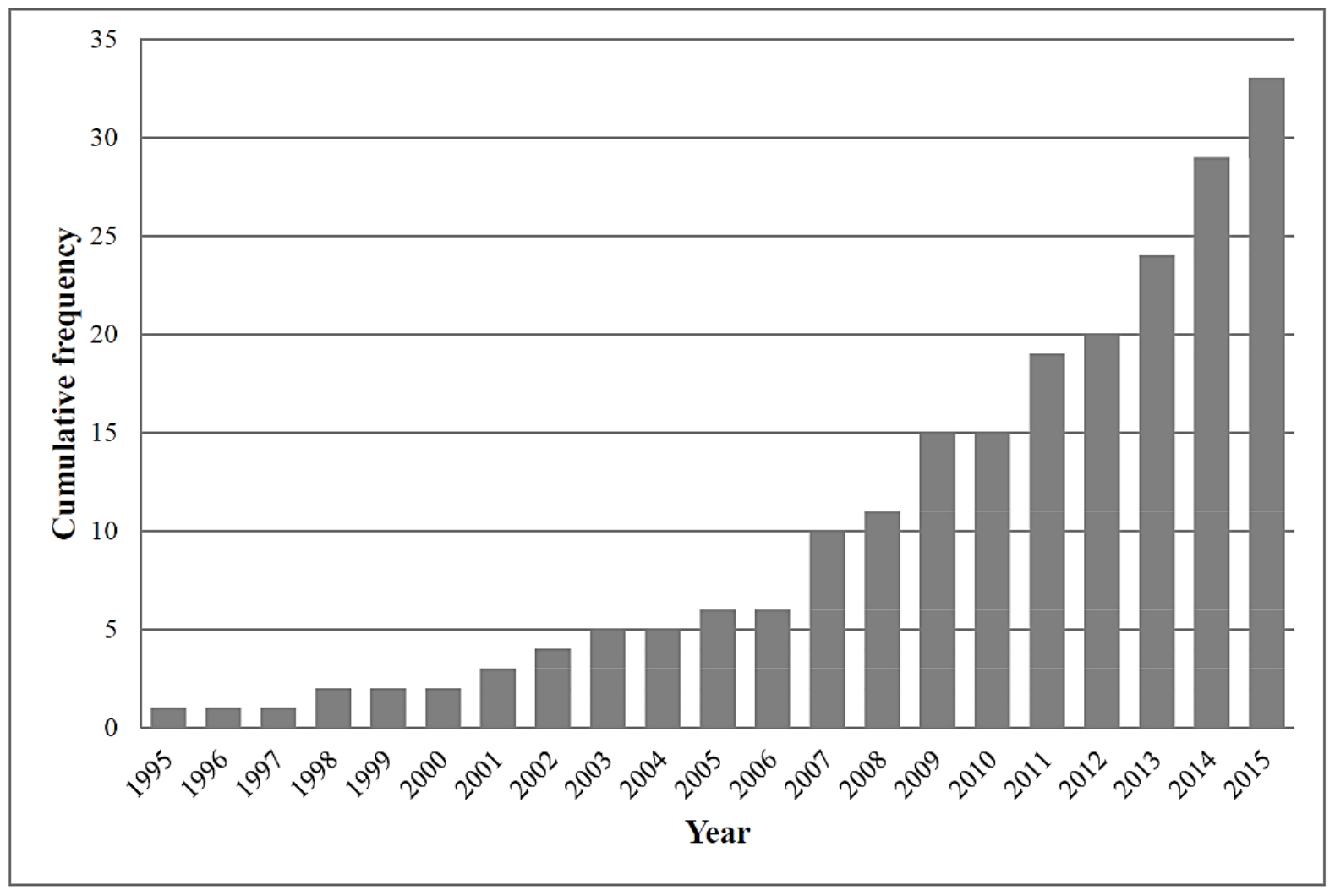

Figure 1. Cumulative frequency of the 33 peer reviewed research papers examining motivation of sport event volunteers by year published. 


\section{Scope by field}

Increasing the attentions about motivation of sport event volunteers, research papers have been studied in 21 different journals with various fields (see Table 2). These involved academic journals in event (30.3\%), sport (27.3\%), leisure (12.1\%), tourism (9.1\%), volunteering (6.1\%), and human resource (3.0 \%). The dominance of journals assessing motivation of sport event volunteers has been found as Event management (15.2 \%) and International Journal of Event and Festival Management (9.1\%).

Table 2. Field and journal distribution of the 33 peer reviewed research papers examining motivation of sport event volunteers

\begin{tabular}{|c|c|c|c|c|}
\hline \multirow[t]{2}{*}{ Field } & \multirow[t]{2}{*}{ Joumal titles } & \multirow{2}{*}{$\begin{array}{l}\text { No. of } \\
\text { papers }\end{array}$} & \multicolumn{2}{|c|}{ Field total } \\
\hline & & & $\mathrm{N}$ & $\%^{1}$ \\
\hline \multirow[t]{4}{*}{ Event (4) } & Event Management & 5 & 10 & 30.3 \\
\hline & $\begin{array}{l}\text { International Journal of Event and Festival } \\
\text { Management }\end{array}$ & 3 & & \\
\hline & Festival Management \& Event Tourism & 1 & & \\
\hline & Journal of Venue and Event Management & 1 & & \\
\hline \multirow[t]{7}{*}{ Sport (7) } & Journal of Sport Management & 2 & 9 & 27.3 \\
\hline & Sport Management Review & 2 & & \\
\hline & International Review for the Sociology of Sport & 1 & & \\
\hline & Sport in Society & 1 & & \\
\hline & International Sports Journal & 1 & & \\
\hline & International Journal of Sport Management & 1 & & \\
\hline & Journal of Sport \& Tourism & 1 & & \\
\hline \multirow[t]{2}{*}{ Leisure (2) } & Managing Leisure & 2 & 4 & 12.1 \\
\hline & Leisure/Loisir & 2 & & \\
\hline \multirow[t]{2}{*}{ Tourism (2) } & $\begin{array}{l}\text { Tourism and Hospitality Planning \& } \\
\text { Development }\end{array}$ & 2 & 3 & 9.1 \\
\hline & Tourism Management & 1 & & \\
\hline Volunteering (1) & Nonprofit and Voluntary Sector Quarterly & 2 & 2 & 6.1 \\
\hline Human Resource (1) & Human Resource Development International & 1 & 1 & 3.0 \\
\hline \multirow[t]{4}{*}{ Other (4) } & Technics Technologies Education Management & 1 & 4 & 12.1 \\
\hline & Team Performance Management & 1 & & \\
\hline & $\begin{array}{l}\text { ICHPER--SD Journal of Research in Health, } \\
\text { Physical Education, Recreation, Sport \& Dance }\end{array}$ & 1 & & \\
\hline & Adapted Physical Activity Quarterly & 1 & & \\
\hline Total & & 33 & 33 & \\
\hline
\end{tabular}

${ }^{1}$ Does not add to $100 \%$ due to rounding. 


\section{Research methods and sample}

A range of methods have been used to examine motivation of sport event volunteers (see Table 3). Most researchers conducted a quantitative research (81.8 \%) rather than a qualitative research (12.1\%). Two of the 33 published papers (6.1\%) used a mixed methods approach. The mostly commonly used method was survey (74.4 \%) which involved online, onsite, and postal. Other methods were interview (11.6 \%), focus group (4.7 \%), observation (4.7 \%), participant observation (2.3\%), and analysis of press coverage (2.3\%).

There were 34 samples selected in the 33 peer reviewed research papers as one paper studied two mega events (see Table 3). The most frequently researched events were mega sport events (76.5\%). Only eight non-mega sport events (23.5 \%) were sampled to study motivation of sport event volunteers.

Table 3. Research methods used and samples in the 33 peer reviewed research papers examining motivation of sport event volunteers

\begin{tabular}{|c|c|c|}
\hline Category & $\mathrm{N}$ & $\%^{2}$ \\
\hline \multicolumn{3}{|l|}{ Methods used } \\
\hline \multicolumn{3}{|l|}{ Details of the methods } \\
\hline Online survey & 13 & 74.4 \\
\hline Onsite survey & 11 & \\
\hline Survey by postal mail & 6 & \\
\hline Survey but not specified & 2 & \\
\hline Interview & 5 & 11.6 \\
\hline Focus group & 2 & 4.7 \\
\hline Observation & 2 & 4.7 \\
\hline Participant observation & 1 & 2.3 \\
\hline Analysis of press coverage & 1 & 2.3 \\
\hline Type of data & \multicolumn{2}{|c|}{33} \\
\hline Quantitative & 27 & 81.8 \\
\hline Qualitative & 4 & 12.1 \\
\hline Both & 2 & 6.1 \\
\hline \multicolumn{3}{|l|}{ Sample } \\
\hline Scale of sport events & \multicolumn{2}{|c|}{$34^{1}$} \\
\hline Mega event & 26 & 76.5 \\
\hline Non-mega event & 8 & 23.5 \\
\hline
\end{tabular}

${ }^{1}$ Total $>33$. One paper by Dickson et al. (2014) examined two mega sport events.

${ }^{2}$ Does not add to $100 \%$ due to rounding. 


\section{Key measurement model/scale}

"Every single construct and item found in different research endeavours may have a great impact on motivation’s clarification and measurement” (Strigas \& Jackson, 2003, p. 114). This paper attempted to categorise key measurement models or scales used in previous research papers in order to identify motivational patterns of sport volunteers in reliable and valid way. A total of six key measurement models or scales were used across the 15 peer reviewed research papers (see Table 4).

Table 4. Key measurement models/scales used in the 33 peer reviewed research papers examining motivation of sport event volunteers

\begin{tabular}{lc}
\hline Key measurement model/scale & $\mathrm{N}$ \\
\hline Motivation but not specified model & 14 \\
Special Event Volunteer Motivation Scale (SEVMS) & 8 \\
Volunteer Motivation Scale for International Sporting Events (VMS-ISE) & 5 \\
Volunteer Functions Inventory (VFI) & 2 \\
Olympic Volunteer Motivation Scale (OVMS) ${ }^{2}$ & 1 \\
Travel Career Pattern & 1 \\
Serious and project-based leisure & 3 \\
No scale due to qualitative data & 1 \\
\hline Total & 4 \\
\hline${ }^{1}$ Total > 33. One paper by Jarvis and Blank (2011) used four scales. \\
${ }^{3}$ Scale used by Giannoulakis et al.'s (2007) study \\
${ }^{3}$ Scales used by Jarvis and Blank's (2011) study
\end{tabular}

Other 14 research papers explored motivation, but they did not use specified models or scales which previous researchers had studied or they modified the measurement items slightly to make the questions specific to a particular case. The rest four papers had no specific scales used due to qualitative data. Nearly half of the reviewed research papers adapted existing measurement scales to measure motivation of sport event volunteers. These measurement scales included Special Event Volunteer Motivation Scale (SEVMS) (used 8 times), Volunteer Motivation Scale for International Sporting Events (VMS-ISE) (used 5 times), Volunteer Functions Inventory (VFI) (used 2 times), Olympic Volunteer Motivation Scale (OVMS) (used once), Travel Career Pattern (used once), and Serious and project-based leisure (used once). The VFI by Clary et al. (1998) and the SEVMS by Farrell et al. (1998) have improved a better understanding of volunteer motivation in general and have been used more broadly than other scales. These scales would be possible to measure common 
volunteer motivations of any relevant volunteering activities. In contrast, the VMS-ISE by Bang and Ross (2009) and the OVMS by Giannoulakis et al. (2007) were particularly oriented towards sport event volunteers as these scales could measure unique motivations regarding the mere love for sport as an incentive for volunteer activity in sport events. Therefore, the adaption of these scales might be found more in other future studies that will target sport events volunteers. Interestingly, Jarvis and Blank (2011) investigated a range of motivations using four different scales framed by Pearce’s (2005) Travel Career Pattern, Farrell et al.’s (1998) SEVMS, Snyder’s (1993) VFI, and Stebbins’s (1992) Serious and project-based leisure. They attempted to explore and compare a range of motivations that are drawn from both the tourism fields (e.g. Pearce, 2005) and volunteer fields (e.g. Farrell et al., 1998; Snyder, 1993; Stebbins, 1992) to show that volunteers travelling to specific sport events might be a potential target market for the tourism industry.

\section{Theoretical basis}

The theories which informed direction and research design in the reviewed research papers were identified and coded (see Table 5). Theories related to motivation of sport event volunteers were applied 17 times in 15 research papers. Two papers discussed more than one theory and over half of the reviewed research papers (54.5\%) did not apply theories. Self-determination theory (Ryan \& Deci, 2000) was the most frequently applied in five papers. Functional theory (Clary et al., 1998; Katz, 1960), incentive theory (Knoke \& Prensky, 1984), and reflexive modernisation theory (Beck, 1992) provided the theoretical frameworks for each two papers. The other theories were discussed in only one of the research papers reviewed. These included motivation theory (Herzberg, 1986; Maslow, 1987), social exchange theory (Blau, 1964; Homans, 1958; Thibaut \& Kelly, 1959), selfregulation theory (Bandura, 1991), theory of habitus (Bourdieu, 1977), theory of sport fan involvement (Laverie \& Arnett, 2000; Shank \& Beasley, 1998), and Emile Durkheim’s Suicide perspective (Durkheim, 1951) which intends to demonstrate the impact of broader social or community process on volunteering rather than the individual level. 
Table 5. Theories used in the 33 peer reviewed research papers examining motivation of sport event volunteers

\begin{tabular}{lc}
\hline Theory & Applied \\
\hline Self-determination theory (Ryan \& Deci, 2000) & 5 \\
Functional theory (Clary et al., 1998; Katz, 1960) & 2 \\
Incentive theory (Knoke \& Prensky, 1984) & 2 \\
Reflexive modernisation theory (Beck, 1992) & 2 \\
Motivation theory (Herzberg, 1986; Maslow, 1987) & 1 \\
Social exchange theory (Blau, 1964; Homans, 1958; Thibaut \& Kelly, 1959) & 1 \\
Self-regulation theory (Bandura, 1991) & 1 \\
Theory of habitus (Bourdieu, 1977) & 1 \\
Theory of sport fan involvement (Laverie \& Arnett, 2000; Shank \& Beasley, 1998) & 1 \\
Emile Durkheim's Suicide perspective (Durkheim, 1951) & 1 \\
\hline Total & $17^{1}$ \\
\hline 1
\end{tabular}

\section{Overall results categorised by research questions}

Of the 33 papers reviewed a total of 33 main research questions were identified (see Table 6).

Table 6. Categories of research questions in the 33 peer reviewed research papers examining motivation of sport event volunteers

\begin{tabular}{lll}
\hline Categories of research questions & $\mathrm{N}$ & \\
\hline Cause and effect & & 16 \\
Motivation-Commitment & 4 & \\
Motivation-Satisfaction & 3 & \\
Motivation-Intention to continue & 2 & \\
Motivation-Commitment-Intention to continue & 2 & \\
Motivation-Satisfaction-Intention to continue & 1 & \\
Motivation-Volunteer work climate-Commitment & 1 & \\
Motivation-Affordances-Satisfaction-Intention to continue & & 13 \\
Difference between motivation factors & 13 & \\
$\quad$ Motivation (incl. socio \& demographic characteristics) & & \\
Relationship between variables & 1 & \\
Motivation-Motivational climate & 1 & \\
Motivation-Expectation & 1 & \\
Motivation-Travel & 1 & \\
Motivation-Tourism & 33 & 33 \\
\hline Total
\end{tabular}

A total of 16 research questions examined 'cause and effect' between independent and dependent variables in terms of volunteer commitment, volunteer satisfaction or volunteer intention to continue. 
A total of 13 research questions focused on 'differences between motivation factors' including socio and demographic characteristics and four research questions examined 'relationships between variables' such as motivational climate, expectation, travel, and tourism. Motivation was used as an independent variable to study sport event volunteer attitudes or behaviours.

In summary, peer reviewed research papers in regard to motivation of sport event volunteers have been focused on particular countries but published in 21 different journal titles across a range of fields. Motivation of sport event volunteers has been the focus of increased research attention over the past 10 years with over four-fifths of the 33 research papers included in this review being published between 2006 and 2015. Most research papers have conducted a quantitative research to collect data using survey methods and have sampled mega sport event volunteers. Key concepts and main research questions influencing results were mostly concerned with measuring motivation of sport event volunteers regarding commitment, satisfaction, and intention to continue. Self-determination theory (Ryan \& Deci, 2000) was the most frequently applied theory. However, more than half of the research papers reviewed did not apply an appropriate theoretical basis.

\section{Discussion}

The aims of systematic review are to identify where research has been studied, by whom, on what, in when, which methods, and what was found. Through this literature review technique, authors can seek the value of emerging and various research areas such as motivation for volunteer management in sport events. It might be useful to make an agenda for future research. Several main findings have emerged from the review: (1) the research is more focused on the United State, Canada, Norway, and the United Kingdom; (2) research interest has increased steadily over the last decade in the fields of event, sport, and leisure; (3) quantitative research methods have been mostly used but qualitative research methods have been limited; (4) motivation scales for sport event volunteers have been developed and modified; (5) over half of the published research papers are not clearly based on the theoretical framework; and, (6) volunteer motivation has been widely measured as an independent variable in the topic linked to volunteer management. 


\section{Geographically focused research}

The research presented that 33 peer reviewed research papers on motivation of sport event volunteers were published across 11 different countries. The majority of the study locations and authors' institutional affiliation, however, are dominated by the United States, Canada, Norway, and the United Kingdom. Over $75 \%$ of the authors were associated with one of the four dominant countries and more than $70 \%$ of the study locations were also from these same countries. Although there are several researches from other countries such as Australia, Germany, Greece, Iran, New Zealand, Malaysia, and Switzerland, the number of reviewed papers may not be as considerable. There are three possible reasons why the United States, Canada, and the United Kingdom among the four dominant countries seem to especially have more research published on this topic in comparison with other countries. First, the systematic review was limited to English language journals. Reviewing in languages other than English may identify a wider range and various trends of sport events and volunteers, emphasising the impact of different culture. Second, it seems that these three dominant countries host more frequently major sport events that need an enormous amount of help from volunteers compared to other countries. According to Müller (2015), he defined and classified the scheme for mega events by developing indicators for four dimensions of mega events: visitor attractiveness, mediated reach, costs, and transformative impact. Based on the indicators, he proposed that the Olympic Games have emerged as a giga event which is the very largest of events (XXL size), European Football Championship, FIFA, Expo, and Asian Games are mega events (XL size), and Commonwealth Games, Universiade, Pan American Games, APEC Summit, European Capital of Culture, Rugby World Cup, and Super Bowl are major events (L size). To the exclusion of non-sport events (e.g. Expo, APEC Summit, European Capital of Culture), the United States, Canada, and the United Kingdom tend to be considered as the dominant countries that host such large sport events. For example, the United States (total eight times) was ranked as a first country by the number of times countries hosted the winter and summer Olympic Games. Both Canada (total three times) and the United Kingdom (total three times) were also ranked in 4th place. The United States also operated many major and mega sport events such as FIFA in 1994, Pan American Games in 1959 \&1987, 
Universiade in 1972 \& 1993, and Super Bowl founded in the United States. Canada hosted Commonwealth Games in 1930, 1954, 1978, \& 1994, Pan American Games in 1967, 1999, \& 2015, and Universiade in 1983. The United Kingdom held FIFA in 1966, European Football Championship in 1996, Commonwealth Games in 1911, 1934, 1958, 1970, 1986, 2002, \& 2014, Universiade in 1991, and Rugby World Cup in 1991, 1999, \& 2015. In effect, it is true that there may be more frequent opportunities for researchers to study sport event volunteers in those countries that host mega sport events more frequently. It is more likely that researchers have explored sport events that are located close to where they study rather than sport events that are held in other countries due to time consuming, financial costs, and transport. Third, academic researchers who are affiliated with institutions in the United States, Canada, and the United Kingdom have collaborated on many projects across different countries. Researchers in affiliations with the United States examined motivation of sport event volunteers with researchers from other countries such as the United Kingdom, Taiwan, Australia, Greece, and Malaysia in six published papers in this review. Researchers in those with the United Kingdom studied this topic with researchers from the United States, Australia, and Canada in three published papers. Researchers who are affiliated with Canada published two research papers in collaboration with researchers from Australia and the United Kingdom. Also, several researchers $(n=14)$ were involved in more than one paper across different countries as well as their affiliation countries (e.g. Allen \& Bartle, 2014; Allen \& Shaw, 2009; Bang et al., 2008; Bang \& Ross, 2009; Bang et al., 2009; Dickson et al., 2013; Dickson et al., 2014; Dickson et al., 2015, Farrell et al., 1998; Khoo \& Engelhorn, 2007; Khoo \& Engelhorn, 2011, Twynam et al., 2002). Such international collaboration is likely to provide opportunities for researchers to develop coordinated research projects and publish more substantial research papers.

\section{Increasing research interest about motivation in the fields of event, sport, and leisure}

The study on motivation of sport event volunteers has been researched for 21 years since the first recognised paper was published in 1995 . The research interest increased slowly during the first decade as measured by published research papers but it has accelerated quickly since 2006. Such increase of research interest about motivation of volunteers can be influenced by the growing economic value of 
the volunteer labour and preference of volunteering in sport and recreation. In the case of the United States, 62.6 million volunteers became involved in volunteering and total annual volunteer hours were 7.8 billion hours in 2015. It was worth $\$ 184$ billion to the United States economy (Corporation for National \& Community Service, 2015). In 2013, 12.7 million Canadians or 44\% of people, aged 15 years and older, participated in some form of volunteer work. They devoted almost 1.95 billion hours to their volunteer activities, a volume of work that is equivalent to about 1 million full-time jobs (Turcotte, 2015). According to Volunteering Australia (2015), the dollar value of the contributions made by Australian volunteers in 2006 and 2010 was estimated based on the average annual number of hours worked multiplied by the average wage rate. In 2006, volunteering was worth $\$ 19.4$ billion to the Australian economy. In 2010, volunteering was worth $\$ 25.4$ billion to the Australian economy. It appears that the contribution of the volunteer workforce has been increased in economic aspects. Such economic value is likely to pay more attention to the research related to volunteer, especially, motivation that influences a decision to volunteer. Preference of volunteering in sport and recreation is also the reason why motivation research has been more studied in the fields of event, sport, and leisure. Among volunteers in the United States in 2015, men who volunteered and parents were most likely to engage in volunteer activities associated with coaching, refereeing, or supervising sports teams (United States Bureau of Labour Statistics, 2016). According to Vézina and Crompton (2012), Sports and recreation organisations got the most support from volunteers in Canada in 2010. 12 \% of people aged 15 and over participated in volunteer work for sports and recreation organisations and these organisations accounted for $19 \%$ of total volunteer hours as compared with other types of organisations such as social services (18\%) and religious organisations (15\%) in Canada. In 2010, the sport and physical recreation sector attracted the largest number of volunteers ( $14 \%$ of the adult population or 2.3 million people) in Australia. People who volunteered for sport and physical recreation organisations in Australia had higher rates of participation in physical activity for exercise or recreation (90\%), compared to other volunteers (80\%) and non-volunteers (65\%) (Volunteering Australia, 2015). It indicates that the largest portion of volunteers is involved in the fields of event, sport, and leisure. Such preference of volunteering in the fields of event, sport, and leisure may give a greater possibility of the critical development about the research of volunteer management as well as 
motivation for researchers. Furthermore, the increasing research interest seems to influence the growth of the relevant industry with a source of volunteer labour. More research about motivation, thus, may lead to enhanced event volunteer management practices to contribute to the successful hosting of sport events.

\section{Mostly used quantitative survey but limited qualitative research methods}

The research methods are the procedure used to collect data for finding out research questions. In order to plan and carry out research, it is necessary for researchers to decide several factors such as the scale of the study area, sample, target, type of event and data. Surveys were used as the dominant method in more than $70 \%$ of the reviewed research papers, representing the quantitative research methods. Survey might be the preferred approach for collecting data as researchers relied on the amount of sources about attitudes or opinions of individual volunteers. In the review, several researchers attempted to do much of their data collection online. Also, other researchers used survey by postal mail and onsite survey as well as online survey or a combination of all modes depending on the type of study and the demographics of respondents. As survey is capable of collecting data from a large number of respondents and numerous questions can be asked, a broad range of data could be collected. Besides, standardised surveys are relatively free from several types of errors in data analysis. It is therefore clear that survey is a main research method in the topic of motivation of sport event volunteers. In connection with survey method, researchers should consider the highest response rates possible to all surveys because the proportion of non-respondents may be too high to be sure that those who responded are representative of the others who did not. To boost survey response rates, researchers may repeat reminder emails to non-respondents or offer incentives to respondents in the form of prizes through a lottery (Nulty, 2008). Also, researchers may achieve high response rates by extending the duration of a survey’s availability (Nulty, 2008).

On the other hand, there are a few research papers that have used qualitative methods or mixed methods. Williams, Dossa, and Tompkins (1995) conducted personal interviews with key informants associated with the special event as well as survey. This approach allowed the researchers to get a 
more qualitative viewpoint of the event's social dimensions. However, their study only selected six key informants of 200 survey respondents. It is one of the limitations of the qualitative research. As qualitative research usually includes relatively small number of participants, it is less likely to be taken seriously by other researchers or by industrial managers. MacLean and Hamm (2007) used mixed methods including survey and interview. Qualitative analysis was conducted to assess the intentions to continue volunteering with 25 randomly selected participants. The researchers could find out key data from randomly selected participants with thoughtful intentions to remain regarding commitment and motivation factors focused on the love of sport and helping the sport grow. Their research could investigate more deeply the connections of meeting motivational needs and intentions to remain through inclusion of qualitative components within motivational instruments. However, issues on privacy and anonymity among randomly selected participants can raise problems to present findings as individuals of target sample have different features case by case in different situations. It can influence the quality of research. Fairley, Kellett, and Green (2007) collected 22 qualitative online survey data as part of a longitudinal study, conducted 14 unstructured interviews, and engaged in participant observation. Their study identified four motives (i.e. nostalgia, camaraderie and friendship, Olympic connection, and sharing and acknowledgement of their expertise) for choosing to travel to volunteer at the Athens 2004 Olympic Games. Interestingly, Fairley et al. (2007) could find that nostalgia has not previously been recognised as a motive for any form of volunteer activity, but it was a main motive driving individuals to travel to volunteer at the Athens Olympics in their qualitative research. Such qualitative research may figure out a problem related to the lack of any previous findings by quantitative research methods. However, qualitative research is comprehensively dependent on the skills of the researcher and more easily affected by the researcher's personal biases. Therefore, it should be careful to discover unknown concepts and develop research framework through the use of qualitative methods. According to Ellis and Bochner (2000), qualitative methods are likely to explore a deep information and rich data including a personal experience, perspective, and feeling. The strength of qualitative research provides new insight through the use of unconventional sources of qualitative data, designs, and analysis. It may be possible to extend the existing ideas. Related areas might have benefited from the adoption of qualitative research methods. 
Although there are several limitations of qualitative research such as small number of participants, issues caused by privacy and anonymity, and researcher's personal biases, future research using qualitative methods may be powerful and sometimes more compelling than quantitative studies.

\section{Motivation scales for sport event volunteers}

Sport event volunteering can be related to episodic volunteers who participate in short-term or onceoff volunteering in local, regional, national, or international sport events. To hold sport events, the event organisation recruits a great number of individuals as episodic volunteers to help athletes, visitors, and spectators. The motivation of episodic volunteers at sport events might be qualitatively different from those of any other volunteers who provide services for non-sport events. Such view has been presented by several reviewed papers (e.g. Bang \& Chelladurai, 2003; Bang \& Ross, 2009; Farrell et al., 1998; Giannoulakis et al., 2007) on volunteer motivation in sport events context. The findings of the reviewed papers indicated that although some common motivations (e.g. altruistic values, social network) were significant to the sport event volunteers, other special motivations related to sport (e.g. love of sport, community involvement, Olympic related values) were also important. Furthermore, the idea of specific motivation of episodic volunteers in sport events is likely to explain that the processes of sport event volunteer management would be different from those associated with non-sport continuous volunteers. Examining specific features and differences on volunteer motivation at sport events, thus, is essential to understand the nature of volunteering for sport events.

From the view of the reviewed papers (e.g. VFI by Clary et al., 1998; SEVMS by Farrell et al., 1998; VMS-ISE by Bang \& Chelladurai, 2003; Bang \& Ross, 2009; OVMS by Giannoulakis et al., 2007), the unique features such as patriotism (Bang \& Chelladurai, 2003), Olympic connection (Fairley et al., 2007; Giannoulakis et al., 2007), and love of sport (Bang et al., 2008; Bang \& Ross, 2009; Bang et al., 2009; Hallmann \& Harms, 2012; VanSickle et al., 2015) may be strong and additional attractions and incentives for sport event volunteers to feel more involved in and contribute to the sport event. The findings support the suggestion that the motivation scales for sport event volunteers might be developed differently from that of volunteers in other contexts. 
Although the reviewed papers have contributed to the understanding of volunteer motivation in sport event context, research in this field has been limited by lack of adequate measurement of volunteer motivation at various sport events. Motivation factors may vary across different cultures and different countries. That is, additional research is necessary to examine whether the motivation scales for sport event volunteers are newly established or replicable in other samples across different countries.

\section{Lack of theoretical framework}

More than half reviewed papers have been limited by the lack of a clear theoretical framework. Fewer than $50 \%$ of the reviewed papers reflected the theoretical basis and of those that articulated theory most papers cited rather than engaged with theory in a way that affected the research design. Kaplan (1964) and Merton (1967) argued that theory is the answer to questions of 'why'. Theory is about the connections among phenomena and stories in terms of why acts, events and thought occur. Also, strong theory is likely to delve into the fundamental perception to understand the systematic reasons for a specific case (Sutton \& Staw, 1995).

Interestingly, the most frequently applied theory within the reviewed papers was the selfdetermination theory. Most definitions of volunteering are related to 'free will or free choice' (Allen \& Shaw, 2009). This concept suggests that self-determination theory may be especially suited to understanding volunteer motivation and relevant concepts such as satisfaction, commitment, and retention. Volunteering behaviours with regard to the level of self-determination, therefore, seem compatible with self-determination theory.

The examination of motivation may be explained in a different way with other theoretical basis. It has indicated that application of appropriate theories tends to lead to substantial outcomes with respect to motivation such as enhanced performance and constant commitment. Thus, a lack of engagement with theory in the reviewed research papers on this topic presents an opportunity for future research to extend a further understanding of sport event volunteers' motivation. Research informed by relevant various theories may be better able to predict and explain motivation in managing sport event volunteers. 


\section{Motivation research linked to volunteer management}

The motivation of sport event volunteers is dominated by studies of volunteer motivation linked to causes of volunteer commitment, satisfaction, and intention to continue as evidenced by the nearly half proportion of studies that examined motivation as a key factor of volunteer management. It is significant for event managers and volunteer coordinators to better understand why volunteers get involved in specific events and what affects their decision to continue to volunteer activities at the event. Therefore, motivation is a good initial topic to develop the strategy of volunteer management in terms of volunteer commitment, satisfaction, and retention. It is likely that volunteer motivation scales such as VMS-ISE, SEVMS, VFI, and OVMS provide an instrument for researchers to examine the concept of motivation. Such measurement driven studies may be allowed to provide a detailed understanding of the effective volunteer management practices by finding out about the motivation of research participants. Furthermore, by motivational segmentation of volunteers, sport event organisers might gain a better understanding of different profiles of sport event volunteers and be able to design more advanced and effective volunteer management strategies. However, one study by Alexander, Kim and Kim (2015) has conducted cluster analysis on sport event volunteers according to their motivation. Alexander et al. (2015) employed seven motivational factors to identify sports-event volunteer segments for the 2012 London Olympic Games. They explored three distinct segments such as the obligated, the enthusiastic, and the semi-enthusiastic and assessed satisfaction, intention to continue volunteering, and socio-demographic backgrounds. The enthusiastic volunteer group was most likely to be motivated and report an intention to continue volunteering compared to the other groups. Their study classified volunteers into homogenous subgroups to better understand and predict behaviour of volunteers. Therefore, this study suggests that future research on sport event volunteer motivation attempts to develop the meaningful segmentation of volunteers and needs to engage with other variables to explain the effectiveness of volunteer management in sport events. 


\section{Conclusions}

The systematic review has presented the current status of the literature on motivation of volunteers in sport events. This paper reviewed and found that the research on this topic is more focused on particular countries (e.g. United States, Canada, Norway, United Kingdom), has increased steadily over the last decade in the fields of event, sport, and leisure, reflects the dominance of quantitative research methods, has developed the specific motivation scales for sport event volunteers, tends to fail to apply a clear theoretical framework, and has influenced the volunteer management.

Evidence from this research identifies that there is an opportunity for the development of a more coordinated research work across different countries, a need for more theoretically applied research, and a use of various methods for more insightfully measured research. Future research on sport event volunteer motivation needs to predict and adapt the effectiveness of volunteer management for a more practical application. Moreover, it may be better to develop and modify the sport event volunteer motivation scales in order to provide a different and useful measurement to examine various aims of research in the field of event, sport, leisure or more. Also, cluster analysis may be a good research idea for further research. This study suggests that a more strategic research agenda through the systematic review may encourage researcher in the aim of better understanding motivation of sport event volunteers and more effective volunteer management.

\section{Geolocation information}

Southport, Queensland, Australia

\section{Disclosure statement}

No potential conflict of interest was reported by the authors. 


\section{References}

Alexander, A., Kim, S. B., \& Kim, D. Y. (2015). Segmenting volunteers by motivation in the 2012 London Olympic Games. Tourism Management, 47, 1-10. doi:10.1016/j.tourman.2014.09.002

Allen, J. B., \& Bartle, M. (2014). Sport event volunteers' engagement: management matters. Managing Leisure, 19(1), 36-50. doi: 10.1080/13606719.2013.849502

Allen, J. B., \& Shaw, S. (2009). “Everyone rolls up their sleeves and mucks in”: Exploring volunteers’ motivation and experiences of the motivational climate of a sporting event. Sport Management Review, 12(2), 79-90. doi: 10.1016/j.smr.2008.12.002

Bandura, A. (1991). Social cognitive theory of self-regulation. Organizational behavior and human decision processes, 50(2), 248-287. Retrieved from http://www.uky.edu/ eushe2/BanduraPubs/Bandura1991OBHDP.pdf

Bang, H., Alexandris, K., \& Ross, S. D. (2008). Validation of the revised volunteer motivations scale for international sporting events (VMS-ISE) at the Athens 2004 Olympic Games. Event Management, 12(3-4), 119-131. doi: 10.3727/152599509789659759

Bang, H., \& Chelladurai, P. (2003, May). Motivation and satisfaction in volunteering for 2002 World Cup in Korea. In conference of the North American Society for Sport Management, Ithaca, New York.

Bang, H., \& Ross, S. D. (2009). Volunteer motivation and satisfaction. Journal of Venue and Event Management, 1(1), 61-77. Retrieved from http://www.sc.edu/study/colleges_schools/hrsm/research/research_journals_and_publications/ jvem_pdfs/vol1_no1/volunteer_motivation.pdf

Bang, H., Won, D., \& Kim, Y. (2009). Motivations, commitment, and intentions to continue volunteering for sporting events. Event Management, 13(2), 69-81. doi: $10.3727 / 152599509789686317$

Beck, U. (1992). Risk Society: Toward a New Modernity. London: Sage.

Blau, P. (1964). Exchange and power in social life. New York, NY: Wiley.

Bourdieu, P. (1977). Outline of a theory of practice. Cambridge, UK: Cambridge University Press. 
Chelladurai, P. (2006). Human resource management in sport and recreation. Champaign, Ill: Human Kinetics.

Clary, E. G., Snyder, M., Ridge, R. D., Copeland, J., Stukas, A. A., Haugen, J., \& Miene, P. (1998). Understanding and assessing the motivations of volunteers: a functional approach. Journal of personality and social psychology, 74(6), 1516-1530. doi:10.1037/0022-3514.74.6.1516

Corporation for National \& Community Service. (2015). National. Retrieved from https://www.nationalservice.gov/vcla/national

Coyne, B. S., \& Coyne Sr, E. J. (2001). Getting, keeping and caring for unpaid volunteers for professional golf tournament events. Human Resource Development International, 4(2), 199216. doi: 10.1080/13678860121999

Cuskelly, G., Hoye, R., \& Auld, C. (2006). Work with volunteers in sport: Theory and Practice. New York, NY: Routledge.

Dickson, T. J., Benson, A. M., Blackman, D. A., \& Terwiel, F. A. (2013). It's all about the games! 2010 Vancouver Olympic and Paralympic winter games volunteers. Event Management, 17(1), 77-92. doi: 10.3727/152599513X13623342048220

Dickson, T. J., Benson, A. M., \& Terwiel, F. A. (2014). Mega-event volunteers, similar or different? Vancouver 2010 vs London 2012. International Journal of Event and Festival Management, 5(2), 164-179. doi: http://dx.doi.org/10.1108/IJEFM-07-2013-0019

Dickson, T. J., Darcy, S., Edwards, D., \& Terwiel, F. A. (2015). Sport mega-event volunteers' motivations and postevent intention to volunteer: The Sydney World Masters Games, 2009. Event Management, 19(2), 227-245.

Doherty, A. (2009). The volunteer legacy of a major sport event. Journal of Policy Research in Tourism, Leisure and Events, 1(3), 185-207. doi: 10.1080/19407960903204356

Downward, P., \& Ralston, R. (2005). Volunteer motivation and expectations prior to the XV Commonwealth Games in Manchester, UK. Tourism and Hospitality Planning \& Development, 2(1), 17-26. doi: 10.1080/14790530500072310

Durkheim, E. (1951). Suicide: A study in sociology. Glencoe, IL: Free Press. 
Ellis, C., \& Bochner, A.P. (2000). Autoethnography, personal narrative, reflexivity. In N.K. Denzin \& Y.S. Lincoln (Eds.), Handbook of Qualitative Research (2nd ed., pp.733-779). Thousand Oaks, CA: Sage.

Fairley, S., Kellett, P., \& Green, B. C. (2007). Volunteering abroad: Motives for travel to volunteer at the Athens Olympic Games. Journal of Sport Management, 21(1), 41-57.

Farrell, J. M., Johnston, M. E., \& Twynam, G. D. (1998). Volunteer motivation, satisfaction, and management at an elite sporting competition. Journal of Sport Management, 12(4), 288-300.

Federation Internationale de Football Association. (2010). South Africa's volunteers prepare for 2010. Retrieved from http://www.fifa.com/worldcup/news/y=2010/m=3/news=south-africavolunteers-prepare-for-2010-1180404.html

Federation Internationale de Football Association. (2014). FIFA World Cup Volunteers: 15,000 heroes. Retrieved from http://www.fifa.com/worldcup/videos/y=2014/m=7/video=fifa-worldcup-volunteers-15-000-heroes-2407340.html

Federation Internationale de Football Association. (2016). Volunteers. Retrieved from http://www.fifa.com/worldcup/organisation/volunteers/

Flueckiger, L. (2015, May 15). Volunteering and Working for the 2016 Olympics in Rio. The Rio Times. Retrieved from http://riotimesonline.com/brazil-news/rio-sports/volunteering-andworking-for-the-2016-olympics-in-rio/\#

Giannoulakis, C., Wang, C. H., \& Gray, D. (2007). Measuring volunteer motivation in mega-sporting events. Event Management, 11(4), 191-200. doi: 10.3727/152599508785899884

Güntert, S. T., Neufeind, M., \& Wehner, T. (2015). Motives for event volunteering extending the functional approach. Nonprofit and Voluntary Sector Quarterly, 44(4), 686-707. doi: $10.1177 / 0899764014527797$

Hallmann, K., \& Harms, G. (2012). Determinants of volunteer motivation and their impact on future voluntary engagement: A comparison of volunteer's motivation at sport events in equestrian and handball. International Journal of Event and Festival Management, 3(3), 272-291. doi: $10.1108 / 17582951211262701$ 
Han, K., Quarterman, J., Strigas, E., Ha, J., \& Lee, S. (2013). Committed sport event volunteers. The ICHPER-SD Journal of Research in Health, Physical Education, Recreation, Sport \& Dance, $8(2), 45-54$.

Herzberg, F. (1986). One more time: How do you motivate employees? In J. N. Williamson (Ed.), The leader-Manager (pp. 433-448). New York: John Wiley \& Sons.

Holmes, K., \& Smith, K. (2009). Managing volunteers in tourism: Destinations, attractions and events. Wallingford: Elsevier Butterworth-Heinemann.

Homans, G. C. (1958). Social behavior as exchange. American journal of sociology, 63(6), 597-606.

International Labour Organisation. (2011). Manual on the Measurement of Volunteer Work. Retrieved from http://www.ilo.org/wcmsp5/groups/public/---dgreports/---dcomm/--publ/documents/publication/wcms_167639.pdf

International Olympic Committee. (2013). Factsheet-London 2012 Facts \& Figures. Retrieved from http://www.olympic.org/Documents/Reference_documents_Factsheets/London_2012_Facts_ and_Figures-eng.pdf

Jarvis, N., \& Blank, C. (2011). The importance of tourism motivations among sport event volunteers at the 2007 World Artistic Gymnastics Championships, Stuttgart, Germany. Journal of Sport \& Tourism, 16(2), 129-147.

Johns Hopkins Centre for Civil Society Studies. (2014). Volunteer Measurement Project (VMP). Retrieved from http://ccss.jhu.edu/research-projects/vmp/

Kaplan, A. (1964). The conduct of inquiry New York. New York, NY: Chandler.

Katz, D. (1960). The functional approach to the study of attitudes. Public opinion quarterly, 24(2), 163-204. Retrieved from http://www.jstor.org/stable/2746402

Khoo, S., \& Engelhorn, R. (2007). Volunteer motivations for the Malaysian Paralympiad. Tourism and Hospitality Planning \& Development, 4(3), 159-167.

Khoo, S., \& Engelhorn, R. (2011). Volunteer motivations at a national Special Olympics event. Adapted physical activity quarterly, 28(1), 27-39. Retrieved from http://journals.humankinetics.com/AcuCustom/Sitename/Documents/DocumentItem/03_Kho o_J3563_27-39.pdf 
Knoke, D., \& Prensky, D. (1984). What relevance do organization theories have for voluntary associations?. Social Science Quarterly, 65(1), 3-20.

Kristiansen, E., Skirstad, B., Parent, M. M., \& Waddington, I. (2014). 'We can do it’: Community, resistance, social solidarity, and long-term volunteering at a sport event. Sport Management Review, 18(2), 256-267.

Laverie, D. A., \& Arnett, D. B. (2000). Factors affecting fan attendance: The influence of identity salience and satisfaction. Journal of leisure Research, 32(2), 225-246. Retrieved from http://www.sagamorepub.com.libraryproxy.griffith.edu.au/products/journal-leisure-research

Lockstone, L., Smith, K., \& Baum, T. (2010). Volunteering flexibility across the tourism sector. Managing Leisure, 15(1-2), 111-127. doi: 10.1080/13606710903448202

Love, A., Hardin, R., Koo, W., \& Morse, A. L. (2011). Effects of motives on satisfaction and behavioral intentions of volunteers at a PGA tour event. International Journal of Sport Management, 12(1), 86-101.

MacLean, J., \& Hamm, S. (2007). Motivation, commitment, and intentions of volunteers at a large Canadian sporting event. Leisure/Loisir, 31(2), 523-556. doi: 10.1080/14927713.2007.9651394

Maslow, A. (1987). Motivation and personality. New York, NY: Harper \& Row.

Merton, R. K. (1967). On Theoretical Sociology: Including Part I of Social Theory and Social Structure: Five Essays, Old and New. New York, NY: Free Press.

Müller, M. (2015). What makes an event a mega-event? Definitions and sizes. Leisure Studies, 34(6), 627-642. doi: 10.1080/02614367.2014.993333

Nulty, D. D. (2008). The adequacy of response rates to online and paper surveys: what can be done?. Assessment \& evaluation in higher education, 33(3), 301-314.

Pauline, G., \& Pauline, J. S. (2009). Volunteer motivation and demographic influences at a professional tennis event. Team Performance Management, 15(3/4), 172-184. doi: $10.1108 / 13527590910964946$

Pearce, P.L. (2005). Tourist behaviour, themes and conceptual schemes. Clevedon: Channel View Publications. 
Petticrew, M. (2001). Systematic reviews from astronomy to zoology: myths and misconceptions. British medical journal, 322(7278), 98-101.

Pickering, C., \& Byrne, J. (2014). The benefits of publishing systematic quantitative literature reviews for PhD candidates and other early-career researchers. Higher Education Research \& Development, 33(3), 534-548. doi: 10.1080/07294360.2013.841651

Roy, S., Byrne, J., \& Pickering, C. (2012). A systematic quantitative review of urban tree benefits, costs, and assessment methods across cities in different climatic zones. Urban Forestry \& Urban Greening, 11(4), 351-363. doi:10.1016/j.ufug.2012.06.006

Ryan, R. M., \& Deci, E. L. (2000). Self-determination theory and the facilitation of intrinsic motivation, social development, and well-being. American psychologist, 55(1), 68-78. doi: 10.1037//0003-066X.55.1.68

Shank, M., \& Beasley, F. (1998). Fan or fanatic: Refining a measure of sport involvement. Journal of sport behavior, 21(4), 435-443. Retrieved from http://www.southalabama.edu/psychology/journal.htm

Sharififar, F., Ganjouie, F. A., Tondnevis, F., \& Zarei, A. (2011). Effect of Social Factors and Motives on Commitment of Sport Events Volunteers. TECHNICS TECHNOLOGIES EDUCATION MANAGEMENT-TTEM, 6(1), 184-190.

Skille, E. Å., \& Hanstad, D. V. (2013). Who are they and why do they do it? The habitus of sport event volunteers in Norway: volunteers at the European handball championship for women 2010. Sport in Society, 16(9), 1135-1148. doi: 10.1080/17430437.2013.790892

Skirstad, B., \& Hanstad, D. V. (2013). Gender matters in sport event volunteering. Managing Leisure, 18(4), 316-330. doi: 10.1080/13606719.2013.809188

Stebbins, R.A. (1992). Amateurs, professionals, and serious leisure. Montreal: McGill-Queens University Press.

Strigas, A. D., \& Jackson Jr, E. N. (2003). Motivating volunteers to serve and succeed: Design and results of a pilot study that explores demographics and motivational factors in sport volunteerism. International Sports Journal, 7(1), 111-123. 
Sutton, R. I., \& Staw, B. M. (1995). What theory is not. Administrative science quarterly, 40 (3), 371384. doi: $10.2307 / 2393788$

Snyder, M. (1993). Basic research and practical problems: the promise of a 'functional' personality and social psychology. Personality and Social Psychology Bulletin, 19(3), 251-264.

Thibaut, J. W., \& Kelley, H. H. (1959). The social psychology of groups. New York, NY: Wiley. Turcotte, M. (2015). Volunteering and charitable giving in Canada. Spotlight on Canadians: results from the General social survey. Retrieved from http://www.statcan.gc.ca/pub/89-652-x/89652-x2015001-eng.pdf

Twynam, G. D., Farrell, J. M., \& Johnston, M. E. (2002). Leisure and volunteer motivation at a special sporting event. Leisure/Loisir, 27(3-4), 363-377. doi: $10.1080 / 14927713.2002 .9651310$

United States Bureau of Labour Statistics. (2016). Volunteering in the United States News Release. Retrieved from https://www.bls.gov/news.release/volun.htm

VanSickle, J. L., Pierce, D. A., \& Diacin, M. (2015). Volunteer motivations at the 2012 Super Bowl. International Journal of Event and Festival Management, 6(3), 166-181. doi: http://dx.doi.org/10.1108/IJEFM-12-2014-0029

Vézina, M., \& Crompton, S. (2012). Volunteering in Canada. Statistics Canada. Retrieved from http://www.statcan.gc.ca/pub/11-008-x/2012001/article/11638-eng.pdf

Volunteering Australia. (2015). Key facts and statistics about volunteering in Australia. Retrieved from http://www.volunteeringaustralia.org/wp-content/uploads/VA-Key-statistics-aboutAustralian-volunteering-16-April-20151.pdf

Welty Peachey, J., Lyras, A., Cohen, A., Bruening, J. E., \& Cunningham, G. B. (2014). Exploring the motives and retention factors of sport-for-development volunteers. Nonprofit and Voluntary Sector Quarterly, 43(6), 1052-1069.

Wicker, P., \& Hallmann, K. (2013). A multi-level framework for investigating the engagement of sport volunteers. European Sport Management Quarterly, 13(1), 110-139. 
Williams, P. W., Dossa, K. B., \& Tompkins, L. (1995). Volunteerism and special event management: A case study of Whistler's Men's World Cup of Skiing. Festival Management and Event Tourism, 3(2), 83-95.

Wollebæk, D., Skirstad, B., \& Hanstad, D. V. (2014). Between two volunteer cultures: Social composition and motivation among volunteers at the 2010 test event for the FIS Nordic World Ski Championships. International Review for the Sociology of Sport, 49(1), 22-41. doi: $10.1177 / 1012690212453355$

Yan, Z., \& Chen, L. (2008). Smiling volunteers win another Olympic gold for Beijing. Chinaview. Retrieved from http://news.xinhuanet.com/english/2008-08/14/content_9321992.htm Yoshioka, C. F., Brown, W. A., \& Ashcraft, R. F. (2007). A functional approach to senior volunteer and non-volunteer motivations. The international journal of volunteer administration, 24(5), 31-43. Retrieved from http://ijova.org/PDF/VOL24_NO5/IJOVA_VOL24_NO5_Yoskioka.pd 


\section{Appendix}

Details of the 33 peer reviewed research papers examining motivation of sport event volunteers

\begin{tabular}{|c|c|c|c|c|c|c|}
\hline $\begin{array}{l}\text { Author (Year/ No. } \\
\text { of authors) }\end{array}$ & Journal & Study location & Theory & Method & Key concepts/variables & $\begin{array}{l}\text { Key measurement } \\
\text { model/scale }\end{array}$ \\
\hline $\begin{array}{l}\text { Alexander et al. } \\
(2015 / 3)\end{array}$ & Tourism Management & United Kingdom & No specific theory & $\begin{array}{l}\text { Quantitative } \\
\text { survey }\end{array}$ & $\begin{array}{l}\text { Motivation, Satisfaction, } \\
\text { Intention to continue }\end{array}$ & $\begin{array}{l}\text { Motivation but not } \\
\text { specified model }\end{array}$ \\
\hline $\begin{array}{l}\text { Allen \& Bartle } \\
(2014 / 2)\end{array}$ & Managing Leisure & United Kingdom & $\begin{array}{l}\text { Self-determination } \\
\text { theory }\end{array}$ & $\begin{array}{l}\text { Quantitative } \\
\text { survey }\end{array}$ & $\begin{array}{l}\text { Motivation, Volunteer work } \\
\text { climate, Commitment }\end{array}$ & $\begin{array}{l}\text { Motivation but not } \\
\text { specified model }\end{array}$ \\
\hline $\begin{array}{l}\text { Allen \& Shaw } \\
\text { (2009/2) }\end{array}$ & Sport Management Review & New Zealand & $\begin{array}{l}\text { Self-determination } \\
\text { theory }\end{array}$ & $\begin{array}{l}\text { Qualitative } \\
\text { focus group }\end{array}$ & $\begin{array}{l}\text { Motivation, Motivational } \\
\text { climate }\end{array}$ & - \\
\hline Bang et al. (2008/3) & Event Management & Greece & No specific theory & $\begin{array}{l}\text { Quantitative } \\
\text { survey }\end{array}$ & Motivation & VMS-ISE \\
\hline $\begin{array}{l}\text { Bang \& Ross } \\
(2009 / 2)\end{array}$ & $\begin{array}{l}\text { Journal of Venue and Event } \\
\text { Management }\end{array}$ & United States & $\begin{array}{l}\text { Self-determination } \\
\text { theory, Self- } \\
\text { regulation theory }\end{array}$ & $\begin{array}{l}\text { Quantitative } \\
\text { survey }\end{array}$ & Motivation, Satisfaction & VMS-ISE \\
\hline Bang et al. (2009/3) & Event Management & United States & $\begin{array}{l}\text { Social exchange } \\
\text { theory }\end{array}$ & $\begin{array}{l}\text { Quantitative } \\
\text { survey }\end{array}$ & $\begin{array}{l}\text { Motivation, Commitment, } \\
\text { Intention to continue }\end{array}$ & VMS-ISE \\
\hline $\begin{array}{l}\text { Coyne \& Coyne Sr } \\
(2001 / 2)\end{array}$ & $\begin{array}{l}\text { Human Resource } \\
\text { Development International }\end{array}$ & United States & No specific theory & $\begin{array}{l}\text { Quantitative } \\
\text { survey }\end{array}$ & Motivation & $\begin{array}{l}\text { Motivation but not } \\
\text { specified model }\end{array}$ \\
\hline $\begin{array}{l}\text { Dickson et al. } \\
(2013 / 4)\end{array}$ & Event Management & Canada & No specific theory & $\begin{array}{l}\text { Quantitative } \\
\text { survey }\end{array}$ & $\begin{array}{l}\text { Motivation, Intention to } \\
\text { continue }\end{array}$ & SEVMS \\
\hline $\begin{array}{l}\text { Dickson et al. } \\
(2014 / 3)\end{array}$ & $\begin{array}{l}\text { International Journal of } \\
\text { Event and Festival } \\
\text { Management }\end{array}$ & $\begin{array}{l}\text { Canada \& } \\
\text { United Kingdom }\end{array}$ & No specific theory & $\begin{array}{l}\text { Quantitative } \\
\text { survey }\end{array}$ & Motivation & SEVMS \\
\hline $\begin{array}{l}\text { Dickson et al. } \\
(2015 / 4)\end{array}$ & Event Management & Australia & No specific theory & $\begin{array}{l}\text { Quantitative } \\
\text { survey }\end{array}$ & $\begin{array}{l}\text { Motivation, Intention to } \\
\text { continue }\end{array}$ & SEVMS \\
\hline $\begin{array}{l}\text { Downward \& } \\
\text { Ralston }(2005 / 2)\end{array}$ & $\begin{array}{l}\text { Tourism and Hospitality } \\
\text { Planning \& Development }\end{array}$ & United Kingdom & No specific theory & $\begin{array}{l}\text { Quantitative } \\
\text { survey }\end{array}$ & Motivation, Expectation & $\begin{array}{l}\text { Motivation but not } \\
\text { specified model }\end{array}$ \\
\hline $\begin{array}{l}\text { Fairley et al. } \\
(2007 / 3)\end{array}$ & $\begin{array}{l}\text { Journal of Sport } \\
\text { Management }\end{array}$ & Australia & No specific theory & $\begin{array}{l}\text { Qualitative } \\
\text { interviews, } \\
\text { participant } \\
\text { observation }\end{array}$ & Motivation, Travel & - \\
\hline
\end{tabular}




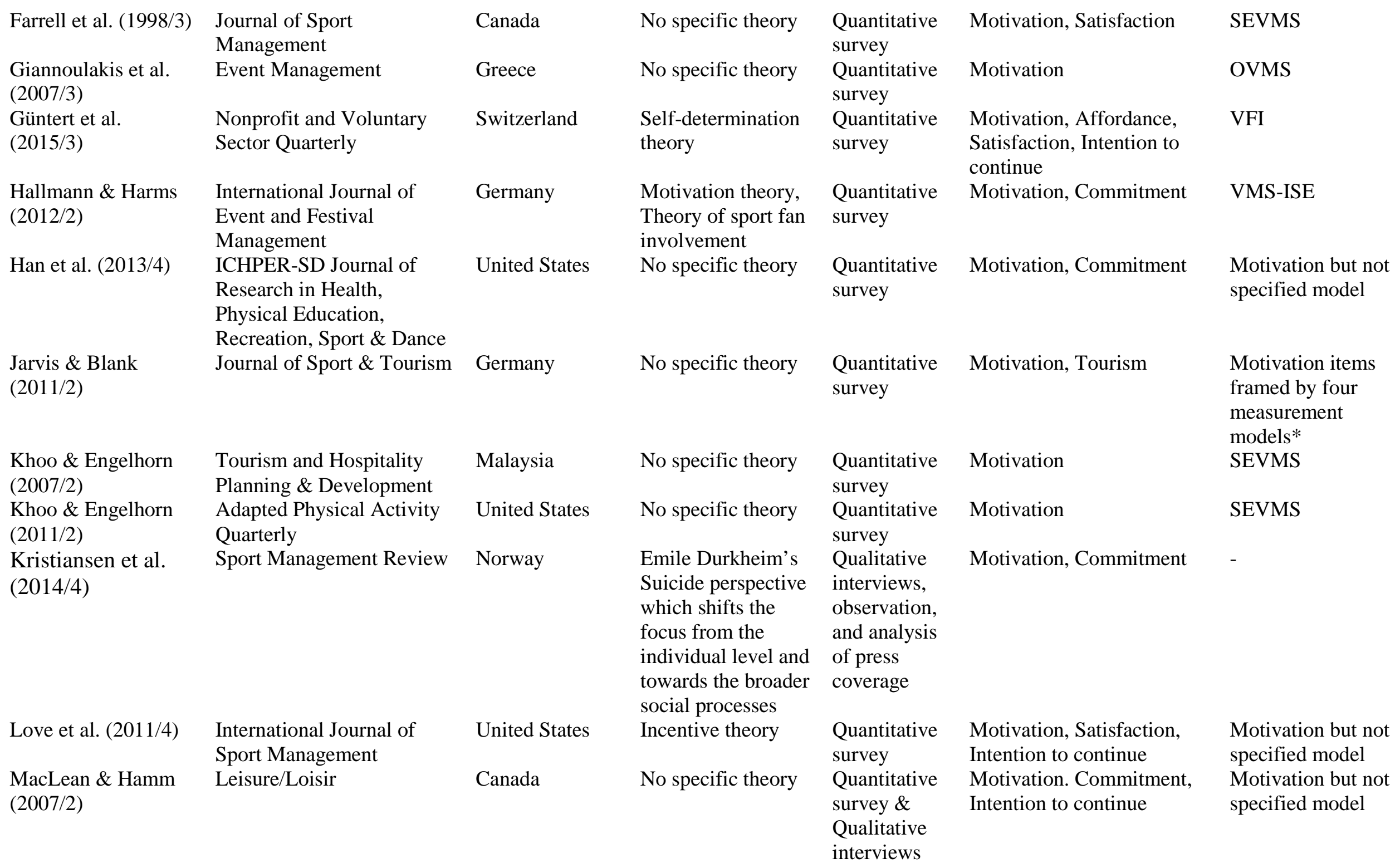




\begin{tabular}{|c|c|c|c|c|c|c|}
\hline $\begin{array}{l}\text { Pauline \& Pauline } \\
(2009 / 2)\end{array}$ & $\begin{array}{l}\text { Team Performance } \\
\text { Management }\end{array}$ & United States & Functional theory & $\begin{array}{l}\text { Quantitative } \\
\text { survey }\end{array}$ & Motivation & $\begin{array}{l}\text { Motivation but not } \\
\text { specified model }\end{array}$ \\
\hline $\begin{array}{l}\text { Sharififar et al. } \\
(2011 / 4)\end{array}$ & $\begin{array}{l}\text { Technics Technologies } \\
\text { Education Management }\end{array}$ & Iran & No specific theory & $\begin{array}{l}\text { Quantitative } \\
\text { survey }\end{array}$ & Motivation, Commitment & $\begin{array}{l}\text { Motivation but not } \\
\text { specified model }\end{array}$ \\
\hline $\begin{array}{l}\text { Skille \& Hanstad } \\
(2013 / 2)\end{array}$ & Sport in Society & Norway & Theory of habitus & $\begin{array}{l}\text { Quantitative } \\
\text { survey }\end{array}$ & Motivation & $\begin{array}{l}\text { Motivation but not } \\
\text { specified model }\end{array}$ \\
\hline $\begin{array}{l}\text { Skirstad \& Hanstad } \\
(2013 / 2)\end{array}$ & Managing Leisure & Norway & $\begin{array}{l}\text { Reflexive } \\
\text { modernisation } \\
\text { theory }\end{array}$ & $\begin{array}{l}\text { Quantitative } \\
\text { survey }\end{array}$ & Motivation & $\begin{array}{l}\text { Motivation but not } \\
\text { specified model }\end{array}$ \\
\hline $\begin{array}{l}\text { Strigas \& Jackson } \\
(2003 / 2)\end{array}$ & International Sports Journal & United States & Incentive theory & $\begin{array}{l}\text { Quantitative } \\
\text { survey }\end{array}$ & Motivation & $\begin{array}{l}\text { Motivation but not } \\
\text { specified model }\end{array}$ \\
\hline $\begin{array}{l}\text { Twynam et al. } \\
(2002 / 3)\end{array}$ & Leisure/Loisir & Canada & No specific theory & $\begin{array}{l}\text { Quantitative } \\
\text { survey }\end{array}$ & Motivation & SEVMS \\
\hline $\begin{array}{l}\text { VanSickle et al. } \\
(2015 / 3)\end{array}$ & $\begin{array}{l}\text { International Journal of } \\
\text { Event and Festival } \\
\text { Management }\end{array}$ & United States & $\begin{array}{l}\text { Self-determination } \\
\text { theory }\end{array}$ & $\begin{array}{l}\text { Quantitative } \\
\text { survey }\end{array}$ & Motivation, Satisfaction & VMS-ISE \\
\hline $\begin{array}{l}\text { Welty Peachey et al. } \\
(2014 / 5)\end{array}$ & $\begin{array}{l}\text { Nonprofit and Voluntary } \\
\text { Sector Quarterly }\end{array}$ & United States & Functional theory & $\begin{array}{l}\text { Qualitative } \\
\text { focus group, } \\
\text { interviews, } \\
\text { observation }\end{array}$ & $\begin{array}{l}\text { Motivation, Intention to } \\
\text { continue }\end{array}$ & - \\
\hline $\begin{array}{l}\text { Williams et al. } \\
(1995 / 3)\end{array}$ & $\begin{array}{l}\text { Festival Management \& } \\
\text { Event Tourism }\end{array}$ & Canada & No specific theory & $\begin{array}{l}\text { Quantitative } \\
\text { survey \& } \\
\text { Qualitative } \\
\text { interviews }\end{array}$ & Motivation & $\begin{array}{l}\text { Motivation but not } \\
\text { specified model }\end{array}$ \\
\hline $\begin{array}{l}\text { Wollebæk et al. } \\
(2014 / 3)\end{array}$ & $\begin{array}{l}\text { International Review for } \\
\text { the Sociology of Sport }\end{array}$ & Norway & $\begin{array}{l}\text { Reflexive } \\
\text { modernisation } \\
\text { theory }\end{array}$ & $\begin{array}{l}\text { Quantitative } \\
\text { survey }\end{array}$ & Motivation & $\begin{array}{l}\text { Motivation but not } \\
\text { specified model }\end{array}$ \\
\hline
\end{tabular}

*Pearce’s (2005) Travel Career Pattern, Farrell et al.’s (1998) SEVMS, Snyder’s (1993) VFI, and Stebbins’s (1992) Serious and project-based leisure. 